\title{
Árangur lungnasmækkunaraðgerða við langvinnri lungnapembu á Íslandi
}

Sverrir I. Gunnarsson ${ }^{1}$ læknir, Kristinn B. Jóhannsson ${ }^{1}$ læknir, Marta Guðojónsdóttir ${ }^{3,5}$ lífeðlisfræðingur, Steinn Jónsson²,5 læknir, Hans J. Beck ${ }^{3}$ læknir, Björn Magnússon ${ }^{4}$ læknir, Tómas Guðbjartsson ${ }^{1,5}$ læknir

\section{ÁGRIP}

Inngangur: Lungnasmækkunaraðgerð (lung volume reduction surgery) getur bætt lungnastarfsemi, líðan og lífshorfur sjúklinga með alvarlega lungnapembu. Tilgangur pessarar rannsóknar var að kanna árangur lungnasmækkunaraðgerða hér á landi.

Efniviður og aðferðir: Framskyggn rannsókn á 16 sjúklingum sem gengust undir lungnasmækkunaraðgerð á Landspítala 1996-2008. Allir sjúklingarnir voru með lungnapembu á háu stigi og aðgerðirnar gerðar í gegnum bringubeinsskurð. Fyrir aðgerð luku allir sjúklingarnir lungnaendurhæfingu. Mælingar á lungnastarfsemi, blóðgösum og poli voru gerðar fyrir og eftir aðgerð. Lifun var könnuð með aðferð Kaplan-Meier og meðaleftirfylgd var 8,7 ár. Niðurstöður: Meðalaldur var 59,2 $\pm 5,9$ ár og áttu allir sjúklingarnir sér langa reykingasögu. Allir sjúklingarnir lifðu aðgerðina af og lifun einu, fimm og tíu árum frá aðgerð var 100\%, 93\% og 63\%. Eftir aðgerð hækkaði fráblástur á einni sekúndu ( $\left.F E V_{1}\right)$ um 35\% ( $\left.p<0,001\right)$, hámarksfráblástur ( $\left.F V C\right)$ um $14 \%(p<0,05)$ og lungnarúmmál (TLC) og loftleif (RV) lækkuðu einnig ( $p<0,05)$. Hlutprýstingur $\mathrm{CO}_{2}$ í slagæðablóði lækkaði einnig eftir aðgerð en hlutprýstingur $\mathrm{O}_{2}$ hélst óbreyttur. Hvorki mældust marktækar breytingar á loftdreifiprófi, poli né hámarksafkastagetu eftir aðgerð. Algengasti fylgikvilli eftir aðgerð var loftleki $(n=7)$. Fimm sjúklingar gengust undir enduraðgerð, oftast vegna loss á bringubeini $(n=4)$.

Ályktun: Lungnastarfsemi batnaði marktækt eftir lungnasmækkun með hækkun á FEV ${ }_{1}$ og FVC, auk lækkunar á lungnarúmmáli og koltvísýringi i blóði. Lifun var svipuð og i erlendum rannsóknum, pó svo að tíðni fylgikvilla og enduraðgerða í pessum rannsóknarhópi væri há.

\section{${ }^{1} \mathrm{Hjarta}-\mathrm{og}$ \\ lungnaskurðdeild, 2lungnadeild Landspítala, ${ }^{3}$ hjarta- og lungnarannsókn Reykjalundi, ${ }^{4}$ Fjórðungssjúkrahúsinu í Neskaupsstað, ${ }^{5}$ ææknadeild Hí.}

Fyrirspurnir: Tómas Guðbjartsson tomasgudbjartsson@ hotmail.com

Barst: 31. maí 2011 - sampykkt til birtingar: 13. október 2011

\section{Inngangur}

Langvinn lungnapemba er sjötta algengasta dánarorsökin á Vesturlöndum en merki um lungnateppu hafa mælst hjá 18\% Íslendinga sem komnir eru yfir fertugt. ${ }^{1}$ Pegar sjúkdómurinn er kominn á alvarlegt stig getur komið til greina að grípa til skurðaðgerðar, helst hjá sjúklingum með ofpenslu á lungum og sjúkdóm sem aðallega er bundinn við efri blöð lungna. ${ }^{2}$ Eftir 1990 var farið að meðhöndla sjúklinga með langt gengna lungnapembu með svokallaðri lungnasmækkunaraðgerð (lung volume reduction surgery). Aðgerðin felst í pví að fjarlægja gisnustu hluta lungnanna, en við pað geta önnur svæði panist betur út og lungnastarfsemi batnað. ${ }^{2}$ Lungnasmækkunaraðgerð er unnt að framkvæma í gegnum bringubeinsskurð eða með brjóstholsskurði beggja vegna, og eru oftast $20-25 \%$ af rúmmáli hvors lunga fjarlægðir með heftibyssu. Á síðari árum hafa pessar aðgerðir verið gerðar í vaxandi mæli með aðstoð brjóstholssjár (video-assisted thoracoscopic surgery) sem virðist fækka fylgikvillum og stytta legutíma. ${ }^{3}$

Lungnasmækkunaraðgerðir voru fyrst gerðar fyrir um fjórum áratugum síðan og skiptar skoðanir hafa verið á gagnsemi hennar, bæði vegna óvissu um ábendingar og misvísandi niðurstaðna um langtímaárangur. ${ }^{4}$ Erlendis hefur bestur árangur náðst hjá sjúklingum með lungnapembu í efri blöðum lungna ${ }^{2,7-7}$ og hefur stór slembivalsrannsókn sýnt fram á bætt lífsgæði og langtímalifun pessara sjúklinga. ${ }^{8}$ Tilgangur pessarar rannsóknar var að meta árangur pessara aðgerða hér á landi en pað hefur ekki verið gert áður á Íslandi.

\section{Efniviður og aðferðir}

\section{Sjúklingar og skilyrði fyrir aðgerð}

Rannsóknin var framskyggn og náði til allra peirra 16 sjúklinga, 10 karla og 6 kvenna, sem gengust undir lungnasmækkunaraðgerð á Landspítala frá 1. janúar 1996 til 31. desember 2008.

Ábending fyrir aðgerð var alvarleg lungnapemba og purftu sjúklingar að uppfylla eftirfarandi skilyrði: a) mikil mæði, prátt fyrir hámarkslyfjameðferð, b) fráblástur á einni sekúndu (forced expiratory volume in 1 second, FEV $V_{1}$ ) undir $30 \%$ af viðmiðunargildi, c) of panin (hyperinflated) lungu og d) svæðisbundin lungnapemba með grisjóttan lungnavef í efri hlutum lungna. Lungnapemba var staðfest með röntgenmynd af brjóstholi og dreifing lungnapembu metin með tölvusneiðmyndum (computed tomography) af brjóstholi. Allir sjúklingarnir tóku pátt í endurhæfingu á Reykjalundi fyrir aðgerð og var pátttaka í henni skilyrði fyrir pví að sjúklingar væru teknir til aðgerðar. Endurhæfing tók að minnsta kosti sex vikur og fengu sjúklingarnir fræðslu, næringarrádgjöf og sálfélagslegan stuðning, auk polpjálfunar.

\section{Skráning upplýsinga}

Skráður var aðgerðartími og hvort fylgikvillar komu upp í aðgerð. Einnig voru skráðir fylgikvillar eftir aðgerðina, bæði fylgikvillar sem greindust pegar sjúklingarnir lágu á sjúkrahúsi og peir sem greindust eftir útskrift. Skráður var heildarlegutími og sá fjöldi daga sem sjúklingar höfðu brjóstholskera í fleiðruholi, en einnig sýkingar, par á meðal skurðsýkingar. Viðvarandi loftleki var skilgreindur sem loftleki í brjóstholskera í meira 
Tafla I. Fylgikvillar hjá 16 sjúklingum sem gengust undir lungnasmækkunaraðgerð á Landspítala 1996-2008. Hver sjúklingur getur haft fleiri en einn fylgikvilla.

\begin{tabular}{lc}
\hline Fylgikvilli & Fjöldi \\
\hline Viðvarandi loftleki $\geq 7$ daga & 7 \\
\hline Enduraðgerð & 5 \\
\hline Los á bringubeini & 4 \\
\hline Blæðing í fleiðruhol & 1 \\
\hline Rof á skeifugörn & 1 \\
\hline Sýking í bringubeini og miðmæti & 1 \\
\hline Lungnabólga & 4 \\
\hline
\end{tabular}

en sjö daga. ${ }^{8}$ Einnig voru kannaðar sérstaklega enduraðgerðir og hvort komið hefði til endurinnlagnar sem rekja mátti til aðgerðarinnar. Skurðdauði (operative mortality) var skilgreindur sem andlát innan 30 daga frá aðgerð. Langtímalifun var könnuð samkvæmt upplýsingum úr Pjóðskrá og miðaðist eftirlit við 31. desember 2010. Meðaleftirfylgd var $8,7 \pm 3,8$ ár (bil 1,8 - 13,6 ár).

\section{Mælingar á lungnastarfsemi og poli}

Mælingar á lungnastarfsemi, poli og blóðgösum voru gerðar fyrir aðgerð eftir endurhæfingu og að meðaltali fjórum vikum eftir aðgerð. Lungnastarfsemi var metin með öndunarmælingu (Gould 2400 spirometer, Gould Instruments; Cleveland, OH) par sem FVC og FEV 1 voru mæld ásamt lungnarúmmáli (total lung capacity, TLC) með helíumpynningaraðferð. Loftskipti voru mæld með single breath $\mathrm{CO}$ aðferð. Polpróf var gert á prekhjóli par sem álag var aukið jafnt og pétt par til sjúklingur gafst upp eða próf stöðvað vegna einkenna. Mæld súrefnisupptaka (SensorMedics Inc.; Yorba Linda, CA) við hámarksálag á polprófi var mælikvarði á pol og hámarksálagið sjálft (í vöttum) var skráð sem hámarksafkastageta sjúklings. Slagæðablóðprufur til mælinga á blóðgösum voru teknar sitjandi í hvíld fyrir polpróf.

\section{Skurðtrkni}

Allar aðgerðirnar voru gerðar í gegnum bringubeinsskurð og framkvæmdi sami skurðlæknir (KJ) pær allar. Notast var við tvíopa berkjurennu, annað lungað fellt saman í einu og 20-30\% af rúmmáli hvors lunga um sig fjarlægð með heftibyssu (GIA AutoSuture, US Surgical, Cincinnati, OH, USA). Til að fyrirbyggja loftleka var notast við Gore-Tex ${ }^{\circledast}$ bætur til að styrkja heftiraðirnar. Í lok aðgerðar var komið fyrir brjóstholskerum í bæði fleiðruhol, peir tengdir við sog $\left(-20 \mathrm{~cm} \mathrm{H}_{2} \mathrm{O}\right)$ og bringubeininu lokað á hefðbundinn hátt með stálvír. Sjúklingarnir voru vaktir á skurðstofu og síðan vistaðir á vöknunardeild í 3-5 klukkustundir áður en peir fluttust á legudeild hjarta- og lungnaskurðdeildar. Brjóstholskerar voru fjarlægðir pegar loftleki hafði ekki sést í rúman sólarhring og bæði lungu vel panin á lungnamynd. Fyrstu dagana eftir aðgerð voru verkir stilltir með dreypi sem gefið var í utanbastslegg, en honum var komið fyrir í upphafi svæfingar. Síðan var notast við hefðbundna verkjastillingu.

\section{Tölfræði}

Fyrir samfelldar breytur voru reiknuð meðaltöl með staðalfráviki eða miðgildi og bil gefið upp par sem við átti. Meðaltöl mælinga fyrir og eftir aðgerð voru borin saman með pöruðu t-prófi. Kaplan-

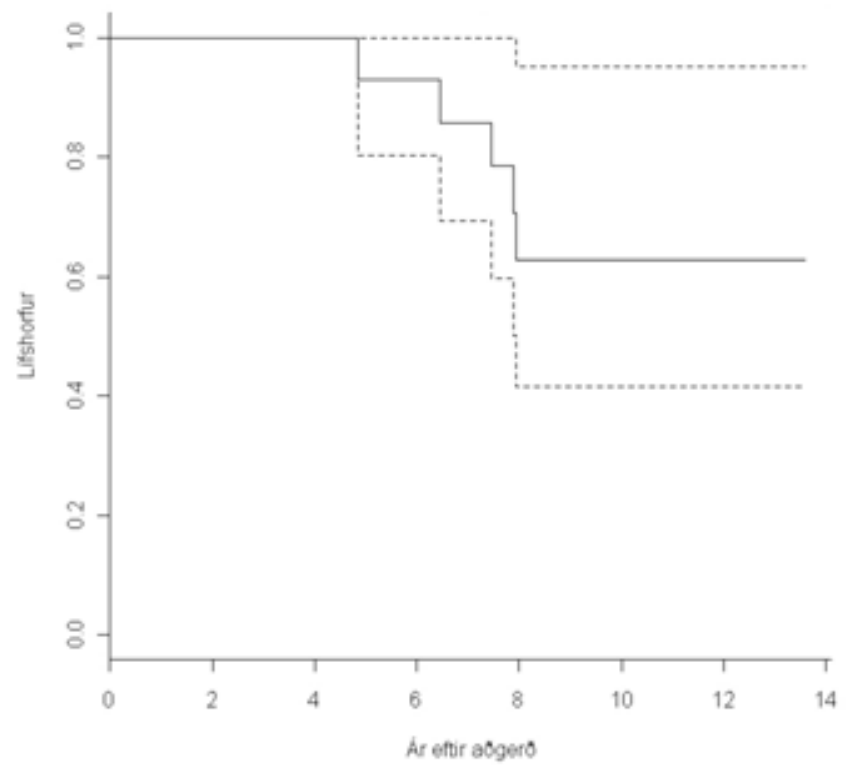

Mynd 1. Lifshorfur (Kaplan-Meier) 16 sjúklinga sem gengust undir lungnasmækkunaraðgerð́ á Íslandi 1996-2008. Lífshorfur eftir eitt, fimm og tíu ár voru 100\%, 93\% og $63 \%$. Brotnar línur sýna 95\% öryggisbil.

Meier aðferð var notuð við útreikning á lífshorfum. Tölfræðileg marktækni miðaðist við p-gildi $<0,05$.

Leyfi

Sjúklingarnir veittu upplýst sampykki fyrir pátttöku í rannsókninni en tilskilin leyfi fengust hjá Siðanefnd Landspítala, Persónuvernd, og lækningaforstjórum Landspítala og Reykjalundar.

\section{Niðurstödur}

Meðalaldur sjúklinganna sextán var 59,2 \pm 5,9 ár (bil 52-72 ár). Sjúklingarnir höfðu allir sögu um reykingar en höfðu hætt reykingum að minnsta kosti sex mánuðum fyrir aðgerðina. Meðalfjöldi pakkaára var $49 \pm 18$ (bil 25-80).

Á fyrri hluta rannsóknartímabilsins (1996-2001) voru gerðar 12 aðgerðir og fjórar á pví síðara (2002-2008). Aðgerðirnar tóku að meðaltali $86 \pm 24$ mínútur (bil 55-135). Fylgikvillar eftir aðgerð eru sýndir í töflu I. Viðvarandi loftleki var algengastur, eða hjá sjö sjúklingum, og fjórir greindust með lungnabólgu. Fimm sjúklingar gengust undir enduraðgerð, par af fjórir vegna loss á bringubeini. Einn sjúkling purfti að endurlífga í enduraðgerð sem gerð var vegna blæðingar í fleiðruhol. Allir sjúklingarnir lifðu af aðgerðina og útskrifuðust af sjúkrahúsi. Miðgildi legutíma var 17 dagar (bil 9-85 dagar). Tveir sjúklingar lágu inni lengur en einn mánuð. Báðir purftu enduraðgerð og fékk annar peirra sýkingu í bringubein og miðmætisbólgu. Við eftirlit voru 11 sjúklinganna á lífi. Dánarorsakir hinna fimm voru öndunarbilun $(n=3)$ og lungnabólga (n=2). Mynd 1 sýnir Kaplan-Meier-graf yfir lífshorfur alls sjúklingahópsins og voru eins, priggja og fimm ára lífshorfur 100\%, 93\% (95\% öryggisbil 80-100\%), 63\% (95\% öryggisbil 42-95\%).

Mælingar á lungnastarfsemi, hlutprýstingi súrefnis og koltvísýrings í slagæðablóði, hámarkssúrefnisupptöku og afkastagetu fyrir og eftir aðgerð eru sýndar í töflu II. FEV 1 hækkaði um $350 \pm$ $220 \mathrm{~mL}$ (p<0,001) og FVC um $370 \pm 360$ mL (p=0,014). Lungnarúm- 
mál og loftleif (residual volume, RV) lækkuðu marktækt eftir aðgerð, einnig hlutprýstingur koltvísýrings í slagæðablóði. Ekki mældust marktækar breytingar á öðrum páttum sem sýndir eru í töflu II.

\section{Umræða}

Í pessari rannsókn sem tók til 16 sjúklinga sem gengust undir lungnasmækkunaraðgerð vegna alvarlegrar lungnapembu var sýnt fram á marktæka hækkun á $\mathrm{FEV}_{1}$ og FVC fjórum vikum eftir aðgerð, en jafnframt lækkun á lungnarúmmáli og koltvísýringi í blóði. Sambærilegum niðurstöðum hefur verið lýst í erlendum rannsóknum 3-18 mánuðum eftir aðgerð., 9-11

Líklegasta skýring á bættri lungnastarfsemi virðist vera sú að pegar gisinn og ofpaninn lungnavefur er fjarlægður, fái aðrir hlutar lungans aukið rými. Einnig eykst teygjanleiki lungnanna, fráblástursgetan verður meiri og minna loft verður eftir í lungunum, auk pess sem styrkur pindarinnar vex. ${ }^{12,13}$ Pessar breytingar auðvelda öndun og sjúklingurinn finnur minna fyrir mæði. ${ }^{14}$ Í stærri rannsóknum erlendis hefur verið sýnt fram á að áðurnefndar breytingar á öndunarmælingum og lungnarúmmáli ná hámarki sex til 12 mánuðum eftir aðgerð, en pær eru oftast gengnar til baka innan fimm ára. ${ }^{15}$ Hlutprýstingur koltvísýrings í slagæðablóði $\left(\mathrm{P}_{\mathrm{a}} \mathrm{CO}_{2}\right)$ lækkaði eftir aðgerð, sem skýrist af bættri öndun, en magn koltvísýrings í blóði er í öfugu hlutfalli við loftflæði í lungnablöðrum. Ekki mældist marktæk hækkun á hlutprýstingi súrefnis í slagæðablóði $\left(\mathrm{P}_{\mathrm{a}} \mathrm{O}_{2}\right)$ en í stærri rannsóknum erlendis hefur verið sýnt fram á hækkun $\mathrm{P}_{\mathrm{a}} \mathrm{O}_{2}$ eftir aðgerð., 11

Allir sjúklingarnir í pessari rannsókn lifðu af aðgerðina. Раð verður að teljast góður árangur en í öðrum rannsóknum er skurðdauði á bilinu 0-17\%.5, 16 Pó verður að taka tillit til pess að sjúklingar í pessari rannsókn voru fáir. Auk pess var $\mathrm{P}_{\mathrm{a}} \mathrm{CO}_{2} 1$ slagæðablóði lægra en í öðrum rannsóknum, en sýnt hefur verið fram á að $\mathrm{P}_{\mathrm{a}} \mathrm{CO}_{2}$ yfir $45 \mathrm{mmHg}$ er sterkur forspárpáttur skurðdauða eftir lungnasmækkunaraðgerð. ${ }^{17}$

Lifun eftir bæði eitt og fimm ár í pessari rannsókn var í hærra lagi miðað við aðrar rannsóknir, en par er fimm ára lifun yfirleitt á bilinu $62-73 \%{ }^{15,18,19}$ Tíu ára lifun í okkar rannsókn var 63\%, en eftir pví sem við best vitum hafa tölur yfir 10 ára lifun ekki verið birtar áður eftir lungnasmækkunaraðgerð.

Langvarandi loftleki var algengasti fylgikvillinn og greindist hjá tæpum helmingi (44\%) sjúklinga. Petta er tiltölulega lág tíðni miðað við aðrar rannsóknir par sem langvarandi loftleki greindist í 46-95\% tilfella eftir aðgerð. ${ }^{2,20,21}$ Loftleki var einnig helsta ástæða langs legutíma sjúklinganna.

Tæpur priðjungur sjúklinga purfti að gangast undir enduraðgerð, oftast vegna pess að bringubein hafði losnað. Petta er mun hærri tíðni enduraðgerða en í öðrum rannsóknum par sem hún hefur verið á bilinu 3-12\%. ${ }^{15}, 22$ Einn sjúklingur fékk sýkingu í bringubein með miðmætisbólgu og annar gekkst undir enduraðgerð vegna blæðingar í fleiðruholi sem stafaði af blæðingu frá lunga. Pennan sjúkling varð að endurlífga í enduraðgerð. Ekki er augljós skýring á hárri tíðni enduraðgerða hér á landi. Ábendingar fyrir aðgerð virðast ápekkar og í öðrum rannsóknum og mismunandi sjúklingapýði skýrir pví varla pennan mun á tíðni fylgikvilla. Lungnasmækkunaraðgerð er tæknilega flókin og fjölda aðgerða parf til að ná góðum tökum á henni. Í pessari rannsókn voru teknar með allar lungnasmækkunaraðgerðir á Íslandi frá upphafi,
Tafla II. Mælingar á lungnastarfsemi, hlutprýstingi súrefnis og koltvísýrings í slagæðablóði, súrefnisupptöku og poli fyrir og eftir lungnasmækkunaraðgerð. Gefin eru upp meðaltöl og prósent af viðmiðunargildi í sviga.

\begin{tabular}{|c|c|c|c|}
\hline Mæling & Fyrir aðgerð & Eftir aðgerð & Breyting \\
\hline $\mathrm{FEV}_{1} \mathrm{~L}$ & $0,97(33)$ & $1,31(45)$ & $\uparrow 35 \%$ ** \\
\hline FVC L & $2,9(74)$ & $3,3(84)$ & $\uparrow 14 \%$ * \\
\hline $\mathrm{FEV}_{1} /$ FVC hlutfall & 33 & 39 & $\uparrow 18 \%$ * \\
\hline TLC L & 7,8 (132) & $7,2(122)$ & $\downarrow 8 \% *$ \\
\hline RV L & 4,3 (199) & $3,7(171)$ & $\downarrow 14 \%{ }^{*}$ \\
\hline DLCO mmól/kPa/mín & $3,2(45)$ & $3,0(42)$ & $\downarrow 7 \%$ \\
\hline $\mathrm{P}_{\mathrm{a}} \mathrm{O}_{2}(\mathrm{mmHg})$ & 71 & 70 & \\
\hline $\mathrm{P}_{\mathrm{a}} \mathrm{CO}_{2}(\mathrm{mmHg})$ & 41 & $38^{\star *}$ & \\
\hline Hámarkssúrefnisupptaka (mL/mín) & 1031 & 1062 & \\
\hline Hámarksafkastageta (W) & 69 & 71 & \\
\hline
\end{tabular}

$\mathrm{FEV}_{1}$ (forced expiratory volume in 1 second), fráblástur á einni sekúndu

FVC (forced vital capacity), hámarksfráblástur

TLC (total lung capacity), lungnarúmmál

RV (residual volume), lungnaleif

DLCO (diffusion capacity for carbon monoxide), loftskipti fyrir kolmónoxíð

$\mathrm{PO}$ hlutbrýstingur súrefnis í slagæðablóði

$\mathrm{P}_{\mathrm{a}}^{\mathrm{a}} \mathrm{CO}_{2}$ hlutprýstingur koltvísýrings í slagæðablóði

${ }^{*} p<0,05{ }^{* *} p<0,01$

og pví líklegt að fylgikvillum hefði fækkað með aukinni reynslu og fjölda aðgerða. Erlendis er í vaxandi mæli farið að gera pessar aðgerðir með brjóstholssjá en fyrstu rannsóknirnar sýndu lakari árangur en við hefðbundna opna aðgerð. ${ }^{20,23}$ Nýlegar rannsóknir benda hins vegar til pess að aðgerðir með brjóstholssjá fækki fylgikvillum og stytti legutíma, sem aftur lækkar kostnað. ${ }^{3}$ Par sem enduraðgerðatíðni vegna bringubeinsvandamála er há hér á landi má leiða líkur að pví að brjóstholssjáraðgerð sé álitlegur kostur við lungnasmækkunaraðgerðir hérlendis. Á síðustu árum hefur lungnasmækkunaraðgerðum pó fækkað verulega hér á landi, líkt og í nágrannalöndum okkar. ${ }^{18}$ Skýringin á pessu er sennilega margpætt, en eflaust skiptir miklu máli að nýir valkostir eru í boði fyrir sjúklinga með alvarlega lungnateppu. Má par sérstaklega nefna einstefnuloka (one-way endobronchial valve) en peim er komið fyrir með berkjuspeglunartækni út í berkjugreinar lungna og lungun pannig minnkuð. ${ }^{24}$

Helsti styrkur pessarar rannsóknar er að gögnum var safnað á framskyggnan hátt hjá öllum sjúklingum sem gengust undir lungnasmækkunaraðgerð hjá heilli pjóð. Að sama skapi er pað veikleiki að sjúklingahópurinn var lítill. Auk pess vantaði upplýsingar um mat á mæði fyrir og eftir aðgerð og sömuleiðis hvernig sjúklingar mátu lífsgæði sín. Slíkar upplýsingar hefðu gefið betri vitneskju um árangur aðgerðanna, eins og gert hefur verið í öðrum rannsóknum. ${ }^{8}$

Niðurstöður pessarar rannsóknar sýna að sjúklingar með alvarlega lungnapembu sem gengust undir lungnasmækkunaraðgerð fengu marktæka hækkun á öndunarmælingum, lækkun á lungnarúmmáli og lækkun á koltvísýringi í blóði. Fimm ára lifun var 93\% sem pykir góður árangur. Hins vegar var tíðni fylgikvilla há, sérstaklega tíðni enduraðgerða.

Pakkir fær Gunnhildur Jóhannsdóttir skrifstofustjóri fyrir aðstoð við leit að sjúkraskrám. Rannsóknin hlaut styrk úr vísinda- og fræðslusjóði Félags fagfólks um hjarta- og lungnaendurhæfingu. 


\section{Heimildir}

1. Benediktsdóttir B, Guðmundsson G, Jörundsdóttir KB Vollmer W, Gíslason P. Hversu algeng er langvinn lungnateppa? - Íslensk faraldsfræðirannsókn. Læknablaðiðð 2007; 93: 471-7.

2. Cooper JD, Patterson GA, Sundaresan RS, et al. Result of 150 consecutive bilateral lung volume reduction procedures in patients with severe emphysema. J Thorac Cardiovasc Surg 1996; 112: 1319-29; discussion 29-30.

3. McKenna RJ, Jr., Benditt JO, DeCamp M, et al. Safety and efficacy of median sternotomy versus video-assisted thoracic surgery for lung volume reduction surgery. J Thorac Cardiovasc Surg 2004; 127: 1350-60.

4. Yusen RD, Lefrak SS, Gierada DS, et al. A prospective evaluation of lung volume reduction surgery in 200 consecutive patients. Chest 2003; 123: 1026-37.

5. Cooper JD, Trulock EP, Triantafillou AN, et al. Bilateral pneumectomy (volume reduction) for chronic obstructive pulmonary disease. J Thorac Cardiovasc Surg 1995; 109 : 106-16; discussion 16-9.

6. Russi EW, Stammberger U, Weder W. Lung volume reduction surgery for emphysema. Eur Respir J 1997; 10: 208-18.

7. Kotloff RM, Tino G, Palevsky HI, et al. Comparison of short-term functional outcomes following unilateral and bilateral lung volume reduction surgery. Chest 1998; 113 890-5.

8. Fishman A, Martinez F, Naunheim K, et al. A randomized trial comparing lung-volume-reduction surgery with medical therapy for severe emphysema. N Engl J Med 2003; 348: 2059-73
9. Date $\mathrm{H}$, Goto $\mathrm{K}$, Souda R, et al. Bilateral lung volume reduction surgery via median sternotomy for severe pulmonary emphysema. Ann Thorac Surg 1998; 65: 939-42.

10. Wilkens H, Demertzis S, Konig J, Leitnaker CK, Schafer HJ, Sybrecht GW. Lung volume reduction surgery versus conservative treatment in severe emphysema. Eur Respir 2000; 16: 1043-9.

11. Miller JD, Berger RL, Malthaner RA, et al. Lung volume reduction surgery vs medical treatment: for patients with advanced emphysema. Chest 2005; 127: 1166-77.

12. Brantigan OC, Mueller E, Kress MB. A surgical approach to pulmonary emphysema. Am Rev Respir Dis 1959; 80 194-206.

13. Criner G, Cordova FC, Leyenson V, et al. Effect of lung volume reduction surgery on diaphragm strength. Am J Respir Crit Care Med 1998; 157: 1578-85.

14. Martinez FJ, de Oca MM, Whyte RI, Stetz J, Gay SE, Celli BR. Lung-volume reduction improves dyspnea, dynamic hyperinflation, and respiratory muscle function. Am J Respir Crit Care Med 1997; 155: 1984-90.

15. Ciccone AM, Meyers BF, Guthrie TJ, et al. Longterm outcome of bilateral lung volume reduction in 250 consecutive patients with emphysema. J Thorac Cardiovasc Surg 2003; 125: 513-25.

16. Geddes D, Davies M, Koyama $\mathrm{H}$, et al. Effect of lung-volume-reduction surgery in patients with severe emphysema. N Engl J Med 2000; 343: 239-45.

17. Szekely LA, Oelberg DA, Wright C, et al. Preoperative predictors of operative morbidity and mortality in COPD patients undergoing bilateral lung volume reduction surgery. Chest 1997; 111: 550-8.
18. Ramsey SD, Shroyer AL, Sullivan SD, Wood DE. Updated evaluation of the cost-effectiveness of lung volume reduction surgery. Chest 2007;131: 823-32.

19. Weder W, Tutic M, Lardinois $D$, et al. Persistent benefit from lung volume reduction surgery in patients with homogeneous emphysema. Ann Thorac Surg 2009;87: 22936; discussion 36-7.

20. Kotloff RM, Tino G, Bavaria JE, et al. Bilateral lung volume reduction surgery for advanced emphysema. A comparison of median sternotomy and thoracoscopic approaches. Chest 1996;110: 1399-406.

21. DeCamp MM, Blackstone EH, Naunheim KS, et al. Patien and surgical factors influencing air leak after lung volume reduction surgery: lessons learned from the Nationa Emphysema Treatment Trial. Ann Thorac Surg 2006; 82: 197-206; discussion -7.

22. Daniel TM, Chan BB, Bhaskar V, et al. Lung volume reduction surgery. Case selection, operative technique, and clinical results. Ann Surg 1996; 223: 526-31; discussion 32-3.

23. Brenner M, McKenna RJ Jr, Gelb AF, Fischel RJ, Wilson AF Rate of FEV1 change following lung volume reduction surgery. Chest 1998; 113: 652-9.

24. Shah PL, Slebos DJ, Cardoso PF, et al. Bronchoscopic lung-volume reduction with Exhale airway stents for emphysema (EASE trial): randomised, sham-controlled multicentre trial. Lancet 2011; 378: 997-1005.

ENGLISH SUMMARY

\section{Lung volume reduction surgery for severe pulmonary emphysema in Iceland}

Gunnarsson SI, Johannsson KB, Gudjonsdottir M, Jonsson S, Beck HJ, Magnusson B, Gudbjartsson T

Introduction: Lung volume reduction surgery (LVRS) can benefit patients with severe emphysema. The aim of this study was to evaluate the outcome of LVRS performed in Iceland.

Materials and methods: A prospective study of 16 consecutive patients who underwent bilateral LVRS through median sternotomy between January 1996 and December 2008. All patients had disabling dyspnea, lung hyperinflation, and emphysema with upper lobe predominance. Preoperatively all patients underwent pulmonary rehabilitation. Spirometry, lung volumes, arterial blood gases and exercise capacity were measured before and after surgery. Mean follow-up time was 8.7 years.

Results: Mean age was $59.2 \pm 5.9$ years. All patients had a history of heavy smoking. There was no perioperative mortality and survival was $100 \%$, $93 \%$, and $63 \%$ at 1,5 , and 10 years, respectively. The forced expiratory volume in 1 second (FEV) and the forced vital capacity (FVC) improved significantly after surgery by $35 \%(\mathrm{p}<0.001)$ and $14 \%(\mathrm{p}<0.05)$, respectively. The total lung capacity, residual volume and partial pressure of $\mathrm{CO} \mathrm{F}_{2}$ also showed statistically significant improvements but exercise capacity, $\mathrm{O}_{2}$ consumption and diffusing capacity of the lung for $\mathrm{CO}$ did not change. Prolonged air leak ( $\geq 7$ days) was the most common complication $(n=7)$. Five patients required reoperation, most commonly for sternal dehiscence $(n=4)$.

Conclusion: In this small prospective study, FEV and FVC increased and lung volumes and $\mathrm{P}_{\mathrm{a}} \mathrm{CO}_{2}$ improved after LVRS. Long term survival was satisfactory although complications such as reoperations for sternal dehiscence were common and hospital stay therefore often prolonged.

Key words: Lung volume reduction surgery (LVRS), emphysema, lung function, complications, outcome, survival. 